\title{
Fermented soybean meal extract improves oxidative stress factors in the lung of inflammation/infection animal model
}

\author{
Saba Miri ${ }^{1,2} \cdot$ Reza Hajihosseini ${ }^{3} \cdot$ Hamed Saedi $^{4} \cdot$ Maryam Vaseghi $^{3} \cdot$ Azadeh Rasooli $^{2,3}$
}

Received: 3 July 2019 / Accepted: 8 November 2019/Published online: 28 November 2019

(C) The Author(s) 2019

\begin{abstract}
Context Fermented soybean products have been used in various ways, and more research is being conducted on them to reveal their benefit.

Objective The objective of this study was to evaluate the antioxidative activity of fermented soybean meal extract by Lactobacillus plantarum in vitro and in vivo tests.

Materials and methods A Lactobacillus plantarum strain RM10 was selected through plate and fermentation experiment, which increased the degree of protein hydrolysis $(1.015 \mu \mathrm{g} / \mathrm{mL})$ and antioxidant activity in soybean meal fermented by selected bacteria (FSBM). In vivo study was done on septic rats as an inflammation/infection model, and then the trial groups were treated with different concentrations of fermented soybean meal extracts (FSBM, 5, 10, and 20\%).

Results DPPH radical-scavenging and ferrozine ion-chelating activity enhanced $(P<0.05)$ after fermentation of soybean meal compared to control group. Reduced $(P<0.05)$ expression of inflammatory genes and enzymes was detected in the lungs of rats treated with fermented soybean meal extract.

Discussion and conclusions These results demonstrated that a diet containing fermented soybean meal extract improved extreme inflammatory response in an infectious disease like sepsis by reducing inflammatory factors.
\end{abstract}

Keywords Fermented soybean meal $\cdot$ Lactobacillus plantarum $\cdot$ Antioxidant activity $\cdot$ Inflammation

\section{Introduction}

It is proven that plant proteins can be alternatives to proteins from animal sources for human nutrition. Soybean meal is the most important source of protein, because of its low price, the security of supply, and good reasonable amino acid profile that can be used as supplements or even as a medicine (Erickson 2015).

Active peptides in fermented foods have benefit human health, and fermented soybeans contain several biological

Azadeh Rasooli

a.rasooli.biochemistry@gmail.com

1 INRS-ETE, Université du Québec, 490 Rue de la Couronne, QC, Québec G1K 9A9, Canada

2 Recombinant Bio Processing Inc., Tehran, Iran

3 Department of Biochemistry, Faculty of Sciences, Payame Noor University, Tehran, Iran

4 Department of Biology, Damghan Branch, Islamic Azad University, Damghan, Iran active peptides with hormone-like effects such as antihypertensive, antioxidant, immunomodulatory, and antimicrobial activities (KIM et al. 2004; Hayes and García-Vaquero 2016; Sanjukta and Rai 2016; Yang et al. 2019). Fermented soybean meal by mixed microorganism exhibits probiotic properties and can be as an alternative for antibiotics (Jazi et al. 2018). Lactic acid fermentation improved the nutritional value and eliminated antinutritional factors and indigestible carbohydrates from soy bean meal (Refstie et al. 2005).

Frias et al. (2008) showed that Lactobacillus plantarum can break down proteins in soybean flour and can use available proteins as nutrient sources during fermentation. In the light of the increasing demand for natural antioxidant resources, investigations at assessing the antioxidant tests in vivo condition are needed.

There are different types of animal models for inflammation/ infection disease known as sepsis, but the cecal ligation and puncture (CLP) resembles the progression and characteristics of human complex immune responses during sepsis. Therefore, CLP is one of the most frequently used procedures to induce experimental sepsis as an inflammation/infection disease in laboratory animals (Dejager et al. 2011). Sepsis is caused by gram- 
negative and gram-positive bacteria, viruses, fungi, and parasites. The tissue damage caused by extreme inflammatory response to infections, and lungs are one of the common locations for infection leading to the development of multiple organ dysfunction and possible death (Gerin et al. 2016).

The purpose of this study was to isolate Lactobacillus sp. in order to improve the production of fermented soybean meal (FSBM) by using Lactobacillus sp. as well-known probiotic organisms. The microorganisms was evaluated and selected by the ability of the protein hydrolysis. Then, the soybean meal was fermented by selected bacteria (Lactobacillus plantarum strain RM10), and the antioxidant potential of the fermented soybean meal extract was investigated by determining its radical scavenging and metal ion chelating properties. Furthermore, as a novel study, the antioxidant activity of the fermented soybean meal extract was evaluated in the inflammation/infection model by determining biochemical and gene expression assays in their lungs.

\section{Materials and methods}

\section{Isolation and identification of bacterial stain}

Lactobacillus plantarum with the highest protease activity was isolated from raw unpasteurized cow milk. The samples were collected under aseptic conditions in a sterile screw cap tubes. Milk samples were enriched in De Man Rogosa Sharpe (MRS) medium and incubated at $37^{\circ} \mathrm{C}$ for $72 \mathrm{~h}$. To screen the protease activity, the isolates were plated onto skim milk agar (containing nutrient agar and $1.5 \%$ skim milk powder). The clear zone diameter was measured in order to reduce the number of further tested isolates. Then, isolated colonies with highest protease activity were picked from MRS agar plate and transferred to MRS broth for identification of the Lactobacilli by $16 \mathrm{~s}$ rRNA gene according to Kumar and Murugalatha (2012).

According to the previous studies, high protease activity can be achieved in the beginning of the exponential growth phase (Wang et al. 2010). To determine the exponential growth phase, the bacteria were cultured in MRS broth at 37 ${ }^{\circ} \mathrm{C}$ for $48 \mathrm{~h}$. Sampling was carried out every $4 \mathrm{~h}$ interval, and the optical density (OD) of samples was measured at $600 \mathrm{~nm}$. The proteolytic activity of bacterial cells was carried out at 5 , 10,15 , and $20 \mathrm{~h}$ according to the method of Kunitz (1947) in order to determine the best time of induction of bacteria to solid-state fermentation substrate.

\section{Fermentation of soybean meal and its quality determination}

Fermented soybean meal (FSBM) was prepared using the selected bacteria with high proteolytic activity. Our results from a previous research in our laboratory showed that the optimal solid-state fermentation conditions of soybean meal with Lactobacillus plantarum were as follows: (1) autoclaved soybean meal with $60 \%$ water content, (2) putting to a $30-\mathrm{cm}$ thick tank, (3) addition of bacteria at $15 \mathrm{~h}$ of bacterial culture (according to the result of growth curve), (4) incubation at 30 ${ }^{\circ} \mathrm{C}$ for $72 \mathrm{~h}$, and $(5)$ drying at $60{ }^{\circ} \mathrm{C}$. The fermented soybean meal extract was prepared with $10 \mathrm{~g}$ of dried fermented soybean meal and $100 \mathrm{ml}$ of distilled water, and then the mixture was centrifuged at $10000 \times \mathrm{g}$ for $20 \mathrm{~min}$ and filtered through a $0.45 \mu \mathrm{m}$ membrane filter. There were 3 replicates for each test, and the control group was defined as a autoclaved soybean meal with $60 \%$ water content without inoculation of bacteria.

Degree of hydrolysis was determined by using orthophthalaldehyde (OPA) according to Silvestre et al. (2013). Briefly, $10 \mu \mathrm{L}$ of the sample was mixed with $3.4 \mathrm{~mL}$ of the OPA reagent, and mixture was allowed to stand at $25^{\circ} \mathrm{C}$ for $2 \mathrm{~min}$. Then, the absorbance was measured at $340 \mathrm{~nm}$.

Hydrolysis of soybean meal protein (before and after fermentation) was analyzed by using electrophoresis of SDS-PAGE according to Chen at al. (2015). Twenty-four micrograms of protein of samples were diluted with $6 \mu \mathrm{g}$ tricine sample buffer and boiled for $5 \mathrm{~min}$ before loading. The gel was run in $130 \mathrm{~V}$ for $100 \mathrm{~min}$, and fixed with $40 \%$ methanol and $10 \%$ acetic acid for 30 min, and then stained with BioSafe Coomassie G250 (Biorad Laboratories, Hercules, CA) and destained with $10 \%$ acetic acid for $30 \mathrm{~min}$ on shaker. The gel was washed with deionized water and then the gel picture was observed.

To determine the antioxidative activity of fermented soybean meal, the scavenging activity was measured based on diphenyl-b-picrylhydrazyl (DPPH) radical scavenging according to the method of He et al. (2012). Briefly, $2 \mathrm{~mL}$ of each sample in methanol was mixed with $2 \mathrm{~mL}$ of methanolic solution containing DPPH radical (final concentration of DPPH was $0.1 \mathrm{M}$ ). The mixture was shaken and left in the dark for $30 \mathrm{~min}$ (at room temperature), and then the absorbance at $517 \mathrm{~nm}$ was measured.

Metal ion-chelating activity of fermented soybean meal was carried out using the method of Chen et al. (2012) based on chelation of $\mathrm{Fe}^{2+}$ activity. Each sample solution $(0.5 \mathrm{~mL})$ was added to $1 \mathrm{~mL}$ of $\mathrm{FeCl}_{2}(20 \mu \mathrm{M})$ and $1 \mathrm{~mL}$ of $0.5 \mathrm{mM}$ ferrozine. After mixing, the reaction mixture was incubated at $25^{\circ} \mathrm{C}$ for $20 \mathrm{~min}$, and then the absorbance was read at $562 \mathrm{~nm}$.

\section{Animal trial}

Male 9-12-week-old Wistar rats (Pasteur Institute, Tehran, Iran) were used in this study. All the animals were housed in a standard environment (temperature, $22 \pm 1{ }^{\circ} \mathrm{C}$; humidity, 50 $\pm 1 \%$; light/dark cycle, $12 / 12 \mathrm{~h}$ ) and given rat chow and water ad libitum. Sepsis was induced by cecal ligation and puncture (CLP) model as described in our previous study (Rasooli et al. 2018). The obtained fermented soybean meal (FSBM) using selected bacteria and its extract was diluted into various 
concentrations $(20,10$, and $5 \%)$ in distilled water and used orally in $12 \mathrm{~h}$ intervals. In this study, the range of $5-20 \%$ was selected referring to low concentration in bioactive peptides and human daily soy protein intake. Some studies showed that bioactive peptides in low concentrations can be more effective than high concentrations. For example, Yang et al. (2009) showed that marine oligopeptide from chum salmon with dose of $0.22 \mathrm{~g} / \mathrm{kg} /$ body weight could be more effective in immune stimulants by enhancing the capacity of lymphocyte proliferation and natural killer cell activity and may strengthen the immune response of its host compared to the dose of 0.45 and $1.35 \mathrm{~g} / \mathrm{kg} / \mathrm{body}$ weight. In addition, Umayaparvathi et al. (2014) reported that bioactive peptide isolated from oyster at a concentration of $1 \mathrm{mg} / \mathrm{ml}$ exhibited a strong antioxidant potential. Also, soy protein consumption across different human populations was reported $\sim 30 \mathrm{~g}$ in Japan, $20 \mathrm{~g}$ in Korea, $7 \mathrm{~g}$ in Hong Kong, $8 \mathrm{~g}$ in China, and $<1 \mathrm{~g}$ in the United States (Nagata 2000; Xiao 2008).

The trial groups were designed as follows:

1. Control group (CO): without any surgery and treatment.

2. Laparotomy group (LAP): the cecum was minimally handled without ligation and puncture due to a combination of the effect of anesthesia, laparotomy, mobilization of abdominal contents, and postoperative analgesia (Brooks et al. 2007).

3. Cecal ligation and puncture group (CLP): with sepsis induction but without treatment.

4. Treatment group $1(5 \%)$ : with sepsis induction and treatment with $5 \%$ fermented soybean meal.

5. Treatment group $2(10 \%)$ : with sepsis induction and treatment with $10 \%$ fermented soybean meal.

6. Treatment group 3 (20\%): with sepsis induction and treatment with $20 \%$ fermented soybean meal.

After $48 \mathrm{~h}$, the rats were euthanized and lungs were collected for further analysis.

\section{Biochemical assays}

\section{Measurement of MDA level}

The malondialdehyde (MDA) level, as index of lipid peroxidation, was determined using MDA assay kit (Teb Pazhouhan Razi (TPR), Tehran, Iran) as previously described by Hosseinzadeh et al. (2019). The absorbance was read at 532 $\mathrm{nm}$. Results were stated as $\mathrm{nmol} / \mathrm{mg}$ of protein.

\section{Measurement of MPO activity}

MPO activity was assessed by myeloperoxidase assay kit $\left(\right.$ Nampox $^{\mathrm{TM}}$ ) at $450 \mathrm{~nm}$. The MPO activity was expressed as $\mu \mathrm{moles} / \mathrm{min} / \mathrm{ml}$ or $\mathrm{mg}$ protein.

\section{Measurement of GSH level}

GSH level was estimated in lung homogenate by procedure of Hillegass et al. (1990). The absorbance of samples was quantified at $412 \mathrm{~nm}$. The GSH content was calculated based on the $\mathrm{nmol} / \mathrm{mg}$ protein.

\section{Measurement of gene expression by real-time PCR}

RNA extraction was performed according to the RNA total kit (Bio Basic Inc., Canada). Complementary DNA was transcripted from total RNA by using PrimeScript ${ }^{\mathrm{TM}}$ RT reagent kit (Takara Bio Inc., Japan). Real-time PCR reactions were performed using SYBR Green PCR Master Mix (QIAGEN, Germany) with Rotor-Gene Q system (QIAGEN, Germany). The fold changes in selected genes were calculated by the formula $2^{-\Delta \Delta \mathrm{Ct}}$. The $\Delta \mathrm{Ct}$ was calculated by subtraction of the GAPDH Ct (as a reference gene) from each sample Ct. Sequence of each primer is shown in Table 1.

\section{Statistical analysis}

The results were statistically analyzed using one-way ANOVA test. Statistically significant differences required that $P<0.05$. All the experiments were done in triplicate and standard deviation was calculated.

\section{Results and discussion}

\section{Determination of bacterial strain and growth rates}

To reduce the number of isolates for identification, gel diffusion method was used onto skim milk agar. The results showed that the each isolate had different activity levels (Table 2). According to this result, it was assumed that RM10 had higher protease activity due to wider clear zone $(2.2 \mathrm{~cm})$. Therefore, isolate RM10 was then selected for identification by using $16 \mathrm{~s}$ rRNA gene. The data from $16 \mathrm{~s}$ sequencing analysis showed that RM10 isolate was the most similar (99\%) to Lactobacillus plantarum subsp. plantarum strain nF1-FD (NCBI GenBank acc. no, CP025285.1). Screening of efficient strain for fermentation of soybean meal reported using protein plate method for isolation of $B$. subtilis BS12 (Zhang et al. 2018). As Lactobacillus plantarum is frequently isolated from food products and is widely used for the industrial production of fermented food (Isa and Razavi 2017), the aim of this study was isolation of lactic acid bacteria for efficient fermentation of soybean meal.

The growth curve of RM10 showed that bacteria are in the middle of the exponential growth phase at $8 \mathrm{~h}$ after culture (Fig. 1). To determine the best time induction of bacteria for solid-state fermentation, the proteolitic activity was 
Table 1 Primer sequences used in this study

\begin{tabular}{lll}
\hline Primers & Sequence $\left(5^{\prime} \rightarrow 3^{\prime}\right)$ & Product length $(\mathrm{bp})$ \\
\hline COX2 forward & ACCTCTGCGATGCTCTTC & 188 \\
COX2 reverse & AGGAATCTCGGCGTAGTAC & 145 \\
CD177 forward & ATACCAGTGCTGACCCTTCTG & \\
CD177 reverse & CCTCGCAGGTTTCTCACC & 165 \\
MPO forward & GCGATAGGTTTTGGTGGGAG \\
MPO reverse & AGCTCACAAAGTCTCGGGG & 193 \\
NF-K $\beta$ forward & CGCAAAAGGACCTACGAGAC \\
NF-K $\beta$ reverse & TGGGGGAAAACTCATCAAAG & 197 \\
GAPDH forward & TGCCAGCCTCGTCTCATAG & \\
GAPDH reverse & ACTGTGCCGTTGAACTTGC & \\
\hline
\end{tabular}

determined in different times in bacterial culture. The maximum proteolytic activity of Lactobacillus $(3.27 \mathrm{U} / \mathrm{ml})$ was obtained at $15 \mathrm{~h}$, while at 5,10 , and $20 \mathrm{~h}$, the proteolitic activity was $1.13,2.5$, and 3.01 , respectively. Since, metabolic activity of bacteria is high in exponential growth (log) phase, protease production in media with high concentration of protein begins in the logarithmic growth phase (Blackburn 1968). In other words, bacteria in the middle of exponential growth are the most active for production of primary metabolites, such as amino acids, enzymes, vitamins, organic acids, and alcohol (Singh et al. 2017), so the best time of induction of bacteria with high proteolytic activity into soybean meal was $15 \mathrm{~h}$ after culture when the bacteria were in the middle of the logarithmic growth phase.

\section{Preparation of fermented soybean meal and quality tests}

As mentioned above, the soybean meal was fermented with RM10, and then its extract was prepared for further analysis. The results from SDS-PAGE showed that fermentation using RM10 decreases protein weight (Fig. 2a), and also, Fig.2b confirmed that fermented soybean meal had the highest

Table 2 Size of the clear zone formed by protease activity of isolates degree of protein hydrolysis $(1.015 \mu \mathrm{g} / \mathrm{ml})$ compared to control test $(0.577 \mu \mathrm{g} / \mathrm{ml})$ that was autoclaved soybean meal without fermentation. Some studies investigated changes in the soybean meal protein profile during fermentation using different bacterial strains (Seo and Cho 2016; Zhang et al. 2018) that are in agreement with the result of this study on the protein hydrolysis by Lactobacillus plantarum.

DPPH radical-scavenging and ferrozine ion-chelating activity were determined for rapid antioxidant evaluation of fermented soybean meal. In this study, the antioxidant tests showed that fermentation improved the antioxidant properties of soybean meal. Similar to the result in our experiment, Amadou et al. (2011) showed that reducing, radical-scavenging, and chelation properties of soy protein meal hydrolysate increased after fermentation using Lactobacillus plantarum LP6 that was obtained from collection of Jiangnan University (China).

Bioactive peptides can be derived from various protein resources by enzymatic proteolysis, they usually contain 320 amino acids, and their activities are related their amino acid composition (Pihlanto-Leppälä et al. 2000). On the other hand, soybean products are rich in isoflavones as an antioxidant agent; fermented soybean products contain high amounts

\begin{tabular}{lc}
\hline Isolates & Clear zone diameter $(\mathrm{cm})$ \\
\hline RM1 & 1.8 \\
RM2 & 1.2 \\
RM3 & 1.5 \\
RM4 & 0.8 \\
RM5 & 1.7 \\
RM6 & 0.9 \\
RM7 & 1.1 \\
RM8 & 1.5 \\
RM9 & 1.1 \\
RM10 & 2.2 \\
RM11 & 1 \\
RM12 & 1.2 \\
\hline
\end{tabular}

Fig. 1 The growth curve of RM10 when cultured in broth media for inoculation of soybean

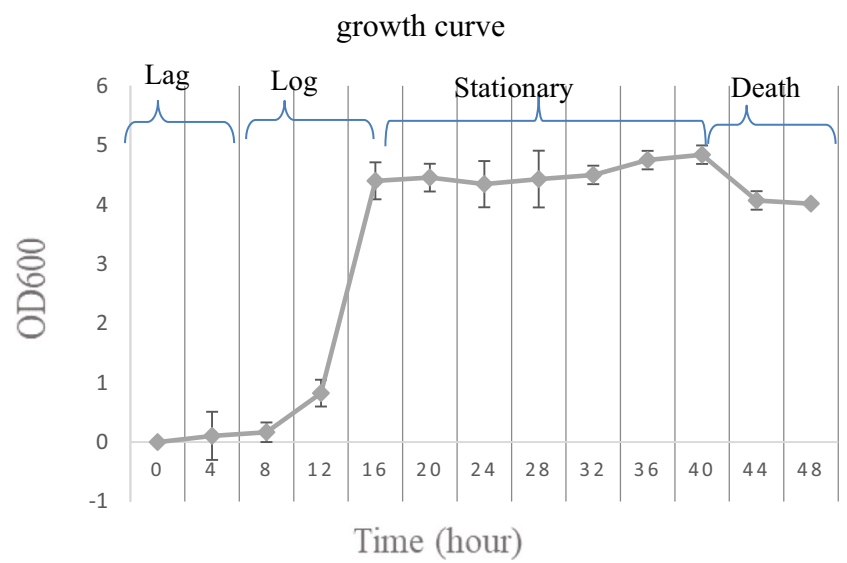


Fig. 2 Quality tests of the fermented soybean meal. (A) SDS-PAGE analysis, Lane 1 and 2 , fermented soybean meal by selected bacteria (duplicate test); Lane 3, control soybean meal; and Lane 4, standard molecular weight marker. (B) Degree of hydrolysis. (C) DPPH radicalscavenging and ferrozine ionchelating activity

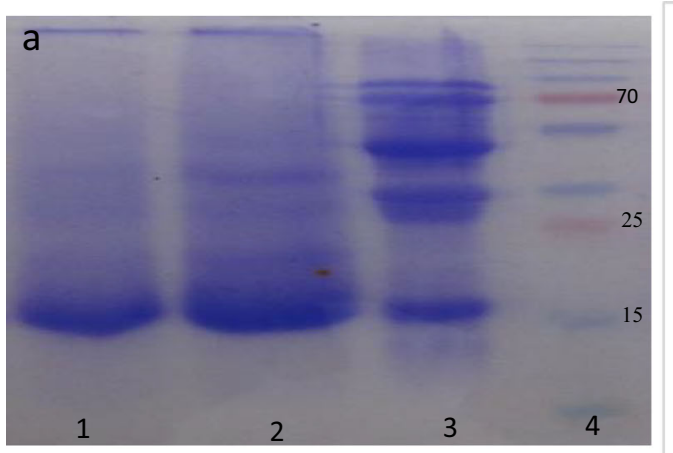

b

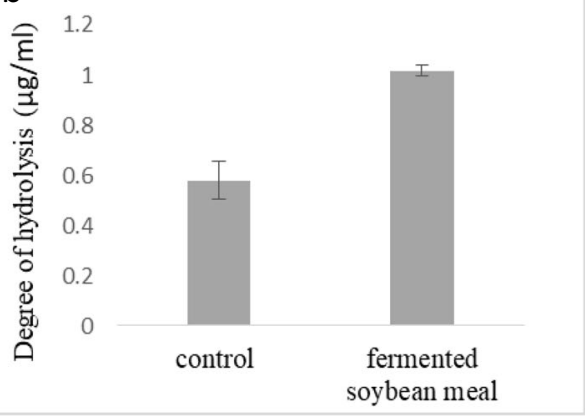

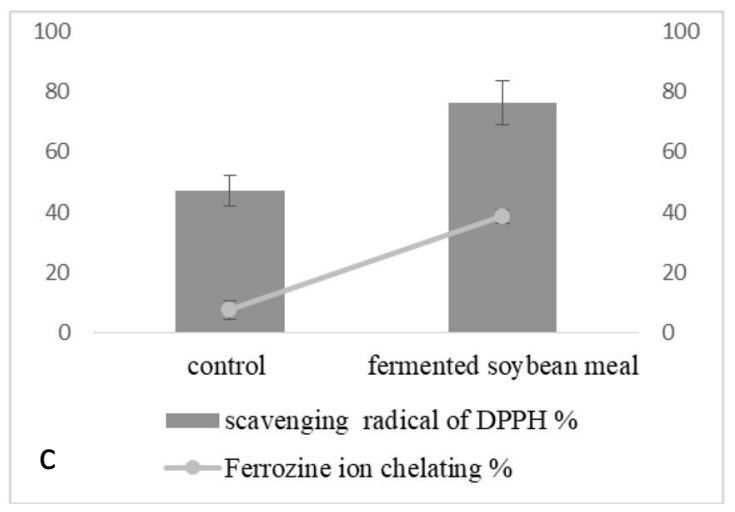

of isoflavone aglycones that can be absorbed faster and in higher amounts than glycosides due to the hydrolysis of glycoside forms by microorganisms' enzymes (Handa et al. 2016; Silva et al. 2018). Okabe et al. reported that food rich in aglycones may improve bioactivity as well as bioavailability.

DPPH is a free radical that becomes a stable product after reacting with antioxidants by accepting a hydrogen atom or an electron from antioxidant compounds. These donate hydrogen from antioxidant to free radicals, leading to inhibition of the propagation phase of lipid oxidation (Jao and Ko 2002). The result of this study (Fig.2C) revealed that fermented soybean meal exhibited a significant DPPH radical-scavenging activity (76.254\%), whereas the activity of control test was $47.115 \%$. This result showed that fermentation process leads to release of some compounds from soybean meal proteins that could react with free radicals as electron donors to convert them to more stable products which terminate the radical chain reaction.

Moreover, the result of ferrozine ion-chelating activity increased by $38.693 \%$ after fermentation process (Fig.2C). It was reported by Moktan et al. (2008) that $\mathrm{Fe}^{2+}$-chelating activity of soy protein meal enhanced after Bacillus-fermentation which was in accordance with our finding. It can be assumed that fermentation with Lactobacillus plantarum RM10 disrupted the structure of soybean meal proteins conducive to trapping and binding of ferrozine ion.

\section{The effects of FSBM on lung biochemical enzyme in septic rats}

Results showed that CLP significantly increased malondialdehyde and myeloperoxidase level as compared to the control and LAP groups $(P<0.05)$. Also, significant change was shown between LAP and control group in level of MDA and MPO. In lung tissue, CLP significantly decreased GSH levels compared to the control and LAP groups $(P<0.05)$. The results of the present study are in concurrence with the reports of the following two studies (Lingaraju et al. 2015; Gerin et al. 2016), supporting the idea that CLP can induce lung injury. These studies showed that CLP could increase total protein, nitrite, MDA, and oxidative stress index and reduced the superoxide dismutase and catalase activity in the lungs and plasma, which were restored by betulinic acid pretreatment. Furthermore, our results showed that treatment with FSBM in 5, 10, and 20\% administration decreased CLP-induced elevation level of MDA and MPO and enhanced the level of GSH $(P<0.05)$ (Fig. 3). MPO is expressed in neutrophils and monocytes during inflammation. It generates reactive oxygen species (ROS) that can oxidatively modify lipids and proteins (Dominguez-Rodriguez and Abreu-Gonzalez 2011). Lipid peroxidation is one of the consequences of sepsis. It is considered as the main oxidative stress parameter which was increased by the impact of free radicals and MPO increment (Song et al. 2016). Ozdulger et al. (2003) reported that MPO activity and MDA concentration were increased in lung tissue by sepsis, which is showed the intensity of neutrophil 


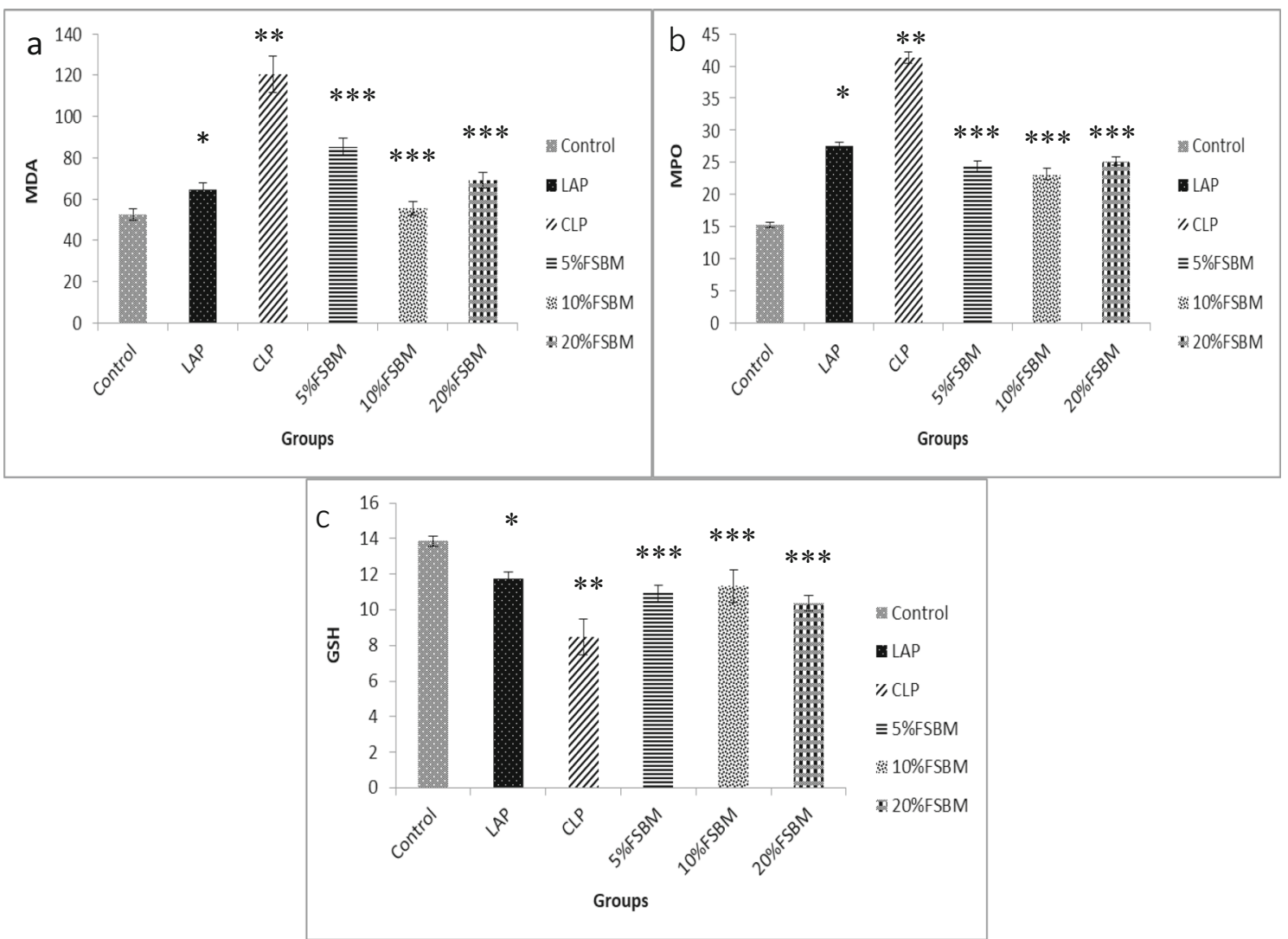

Fig. 3 The effects of FSBM on biochemical enzymes. (A) Malondialdehyde (MDA). (B) Myeloperoxidase (MPO). (C) Glutathione (GSH). ${ }^{*} P<0.05$ is significantly considered between control and LAP group. ${ }^{* *} P<0.05$ is significantly considered between LAP and CLP group. ${ }^{* * *} P<0.05$ is significantly considered between CLP and treated groups. Data are presented as mean $\pm \mathrm{SD}$ infiltration and oxidative stress condition. Also, there is relation between lipid peroxidation and GSH depletion in sepsis. GSH is considered as an important natural antioxidant system that can deal with ROS production (Zhong et al. 2016). The rise in LP level concomitant with diminished GSH level (Fig. 3) indicated the role of oxidative mechanism in sepsis-induced tissue damage (Şener et al. 2005; Coskun et al. 2011). Studies showed that active peptides with antioxidative and immunomodulatory properties produced during the fermentation process (Korhonen and Pihlanto 2003; Sachindra and Bhaskar 2008). Moreover, our results are in conjunction with other studies, which showed that CLP could alter the level of antioxidant enzyme in liver and lung tissues, while pretreatment with Rosa damascena and Mentha longifolia essential oils could modulate the level of MPO, GSH, and LP (Dadkhah et al. 2018, 2019).

\section{The effects of FSBM on gene expression}

As shown in Fig. 4, results revealed that the expression of COX-2, MPO, CD177, and NF- $\mathrm{BB}$ genes as inflammatory factors increased by LAP and CLP surgery compared with control group. It should be noted that significant elevation was observed between LAP and CLP group $(P<0.05)$ in all gene expressions. A similar observation was also made in the current study for gene expression of MPO, CD177, and NF- $\mathrm{BB}$ (Rasooli et al. 2018). NF- $\mathrm{KB}$ has an important role in the expression of factors involved in inflammation, apoptosis, adhesion, and also immune and stress responses (Giusti et al. 2017). One study showed that inhibition of NF-kB could be a promising therapeutic target in sepsis (Ding et al. 2009). Also, myeloperoxidase is a heme enzyme of neutrophil azurophilic granules that have a strong oxidative activity (Khowailed et al. 2015). Elevated MPO levels in sepsis can be due to leakage of MPO into the plasma when neutrophil phagocytize bacteria (Kovach and Standiford 2012). On the other hand, CD177 is expressed by neutrophils, and measurement of CD177 mRNA levels is a useful diagnostic tool for distinguishing some infectious diseases (Demaret et al. 2016; Bai et al. 2017).

As tissue damage, multiple organ failure especially the lungs, sepsis, and death occurred by overproduction of ROS and inflammatory cytokines (Gerin et al. 2016) the balance of the inflammatory and oxidative status of the body could be one of the pharmacologic approaches 


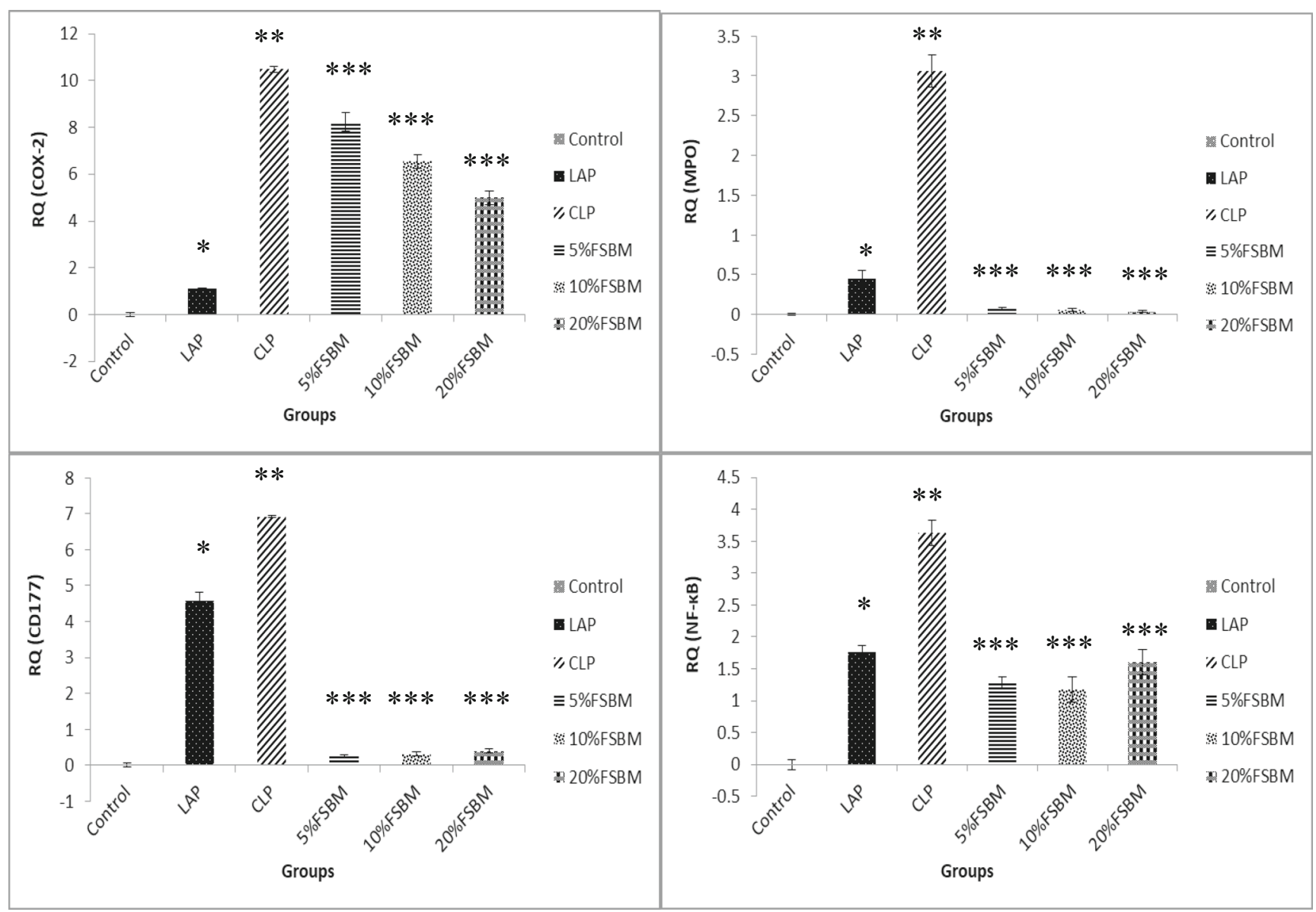

Fig. 4 The effects of FSBM on gene expression of COX-2, MPO, $\mathrm{CD} 177$, and NF-k $\beta$. ${ }^{*} P<0.05$ is significantly considered between control and LAP group. ${ }^{* *} P<0.05$ is significantly considered between

LAP and CLP group. ${ }^{* * * *} P<0.05$ is significantly considered between CLP and treated groups. Data are presented as mean \pm SD

for treatment of lung injury. The result of this study showed that rats in the FSBM treatment groups had a reduction level of gene expression compared with the CLP group $(P<0.05)$ (Fig. 4). Therefore, it can be concluded that anti-inflammatory effects of FSBM could be a potential therapeutic agent for lung injury in sepsis.

\section{Compliance with ethical standards}

Conflict of interest The authors declare that they have no conflict of interest.

Ethical approval Animal experimentation was performed according to ethical committee and institutional animal care and ethical guidelines.

Open Access This article is distributed under the terms of the Creative Commons Attribution 4.0 International License (http:// creativecommons.org/licenses/by/4.0/), which permits unrestricted use, distribution, and reproduction in any medium, provided you give appropriate credit to the original author(s) and the source, provide a link to the Creative Commons license, and indicate if changes were made.

\section{References}

Amadou I, Le G-W, Shi Y-H, Jin S (2011) Reducing, radical scavenging, and chelation properties of fermented soy protein meal hydrolysate by Lactobacillus plantarum LP6.

Bai M, Grieshaber-Bouyer R, Wang J, Schmider AB, Wilson ZS, Zeng L, Halyabar O, Godin MD, Nguyen HN, Levescot A et al (2017) CD177 modulates human neutrophil migration through activation-mediated integrin and chemoreceptor regulation. Blood. 130(19):2092-2100

Blackburn TH (1968) Protease production by Bacteroides amylophilus strain $\mathrm{H}$ 18. Microbiology. 53(1):27-36

Brooks HF, Osabutey CK, Moss RF, Andrews PLR, Davies DC (2007) Caecal ligation and puncture in the rat mimics the pathophysiological changes in human sepsis and causes multi-organ dysfunction. Metab Brain Dis 22(3):353-373

Chen N, Yang H, Sun Y, Niu J, Liu S (2012) Purification and identification of antioxidant peptides from walnut (Juglans regia L.) protein hydrolysates. Peptides. 38(2):344-349

Chen L, Vadlani PV, Madl RL, Wang W, Shi Y, Gibbons WR (2015) The investigation of virginiamycin-added fungal fermentation on the size and immunoreactivity of heat-sensitive soy protein. Int J Polym Sci 2015:7 
Coskun AK, Yigiter M, Oral A, Odabasoglu F, Halici Z, Mentes O, Cadirci E, Atalay F, Suleyman H(2011) The effects of montelukast on antioxidant enzymes and proinflammatory cytokines on the heart, liver, lungs, and kidneys in a rat model of cecal ligation and puncture-induced Sepsis. ScientificWorldJournal 11:13411356

Dadkhah A, Fatemi F, Rasooli A, Mohammadi Malayeri MR, Torabi F (2018) Assessing the effect of Mentha longifolia essential oils on COX-2 expression in animal model of sepsis induced by caecal ligation and puncture. Pharm Biol 56(1):495-504

Dadkhah A, Fatemi F, Mohammadi Malayeri M, Karvin Ashtiyani M, Kazemi Noureini S, Rasooli A (2019) Considering the effect of Rosa Damascena essential oil on oxidative stress and COX-2 gene expression in liver of septic rats. Turkish journal of pharmaceutical science.

Dejager L, Pinheiro I, Dejonckheere E, Libert C (2011) Cecal ligation and puncture: the gold standard model for polymicrobial sepsis? Trends Microbiol 19(4):198-208

Demaret J, Venet F, Plassais J, Cazalis M-A, Vallin H, Friggeri A, Lepape A, Rimmelé T, Textoris J, Monneret G (2016) Identification of CD177 as the most dysregulated parameter in a microarray study of purified neutrophils from septic shock patients. Immunol Lett 178:122-130

Ding J, Song D, Ye X, Liu SF (2009) A pivotal role of endothelialspecific NF-KB signaling in the pathogenesis of septic shock and septic vascular dysfunction. J Immunol 183(6):4031-4038

Dominguez-Rodriguez A, Abreu-Gonzalez P (2011) Current role of myeloperoxidase in routine clinical practice. Expert Rev Cardiovasc Ther 9(2):223-230

Erickson DR (2015) Practical handbook of soybean processing and utilization. Elsevier

Frias J, Song YS, Martínez-Villaluenga C, De Mejia EG, Vidal-Valverde $\mathrm{C}$ (2008) Immunoreactivity and amino acid content of fermented soybean products. J Agric Food Chem 56(1):99-105

Gerin F, Sener U, Erman H, Yilmaz A, Aydin B, Armutcu F, Gurel A (2016) The effects of quercetin on acute lung injury and biomarkers of inflammation and oxidative stress in the rat model of sepsis. Inflammation. 39(2):700-705

Giusti L, Gabriele M, Penno G, Garofolo M, Longo V, Del Prato S, Lucchesi D, Pucci L (2017) A fermented whole grain prevents lipopolysaccharidesinduced dysfunction in human endothelial progenitor cells. Oxidative Med Cell Longev 2017:13

Handa, C. L., de Lima, F. S., Guelfi, M. F. G., Georgetti, S. R., \& Ida, E. I. (2016). Multi-response optimisation of the extraction solvent system for phenolics and antioxidant activities from fermented soy flour using a simplex-centroid design. Food chemistry, 197, 175-184.

Hayes M, García-Vaquero M (2016) Bioactive compounds from fermented food products. In: Ojha KS, Tiwari BK (eds) Novel food fermentation technologies. Springer International Publishing, Cham, pp 293-310

He R, Ju X, Yuan J, Wang L, Girgih AT, Aluko RE (2012) Antioxidant activities of rapeseed peptides produced by solid state fermentation. Food Res Int 49(1):432-438

Hillegass LM, Griswold DE, Brickson B, Albrightson-Winslow C (1990) Assessment of myeloperoxidase activity in whole rat kidney. $\mathrm{J}$ Pharmacol Methods 24(4):285-295

Hosseinzadeh A, Houshmand G, Goudarzi M, Sezavar SH, Mehrzadi S, Mansouri E, Kalantar M (2019) Ameliorative effect of gallic acid on sodium arsenite-induced spleno-, cardio- and hemato-toxicity in rats. Life Sci 217:91-100

Isa, J. K., \& Razavi, S. H. (2017). Characterization of Lactobacillus plantarum as a potential probiotic in vitro and use of a dairy product (yogurt) as food carrier. Applied Food Biotechnology, 4(1), 11-18

Jao C-L, Ko W-C (2002) 1, 1-Diphenyl-2-picrylhydrazyl (DPPH) radical scavenging by protein hydrolyzates from tuna cooking juice. Fish Sci 68(2):430-435
Jazi V, Ashayerizadeh A, Shabani A, Toghyani M, Tellez G, Toghyani M (2018) Fermented soybean meal exhibits probiotic properties when included in Japanese quail diet in replacement of soybean meal. Poult Sci 97(6):2113-2122

Khowailed A, Younan SM, Ashour H, Kamel AE, Sharawy N (2015) Effects of ghrelin on sepsis-induced acute kidney injury: one step forward. Clin Exp Nephrol 19(3):419-426

Kim H-W, Kim K-M, Ko E-J, Lee S-K, Ha S, Song K-B, Park S-K, Kwon K-S, Bae D-H (2004) Development of antimicrobial edible film from defatted soybean meal fermented by Bacillus subtilis. J Microbiol Biotechnol 14(6):1303-1309

Korhonen H, Pihlanto A (2003) Food-derived bioactive peptides - opportunities for designing future foods. Curr Pharm Des 9(16):12971308

Kovach MA, Standiford TJ (2012) The function of neutrophils in sepsis. Curr Opin Infect Dis 25(3):321-327

Kumar AM, Murugalatha N (2012) Isolation of Lactobacillus plantarum from cow milk and screening for the presence of sugar alcohol producing gene. J Microbiol Antimicrob 4(1):16-22

Kunitz, M. (1947) Crystalline soybean trypsin inhibitor: II. General properties. The Journal of General Physiology, 30(4), 291-310.

Lingaraju MC, Pathak NN, Begum J, Balaganur V, Bhat RA, Ram M, Kumar D, Kumar D, Tandan SK (2015) Betulinic acid negates oxidative lung injury in surgical sepsis model. J Surg Res 193(2):856-867

Moktan B, Saha J, Sarkar PK (2008) Antioxidant activities of soybean as affected by Bacillus-fermentation to kinema. Food Res Int 41(6): $586-593$

Nagata C (2000) Ecological study of the association between soy product intake and mortality from cancer and heart disease in Japan. Int $\mathrm{J}$ Epidemiol 29(5):832-836

Ozdulger A, Cinel I, Koksel O, Cinel L, Avlan D, Unlu A, Okcu H, Dikmengil M, Oral U (2003) The protective effect of Nacetylcysteine on apoptotic lung injury in cecal ligation and puncture-induced sepsis model. Shock. 19(4):366-372

Pihlanto-Leppälä, A., Koskinen, P., Piilola, K., Tupasela, T., \& KORHONEN, H. (2000) Angiotensin I-converting enzyme inhibitory properties of whey protein digests: concentration and characterization of active peptides. Journal of Dairy Research, 67(1), 53-64.

Rasooli A, Ghafari E, SAEIDI H, Miri S (2018) Expression changes of CD177 and MPO as novel biomarkers in lung tissue of CLP model rats. Turk J Med Sci 48(6):1321-1327

Refstie S, Sahlström S, Bråthen E, Baeverfjord G, Krogedal P (2005) Lactic acid fermentation eliminates indigestible carbohydrates and antinutritional factors in soybean meal for Atlantic salmon (Salmo salar). Aquaculture. 246(1):331-345

Sachindra NM, Bhaskar N (2008) In vitro antioxidant activity of liquor from fermented shrimp biowaste. Bioresour Technol 99(18):90139016

Sanjukta S, Rai AK (2016) Production of bioactive peptides during soybean fermentation and their potential health benefits. Trends Food Sci Technol 50:1-10

Sener G, Arbak S, Kurtaran P, Gedik N, Yeğen BC (2005) Estrogen protects the liver and intestines against sepsis-induced injury in rats. J Surg Res 128(1):70-78

Seo S-H, Cho S-J (2016) Changes in allergenic and antinutritional protein profiles of soybean meal during solid-state fermentation with Bacillus subtilis. LWT Food Sci Technol 70:208-212

Silva, M. O., Brigide, P., Toledo, N. M. V. D., \& Canniatti-Brazaca, S. G. (2018). Phenolic compounds and antioxidant activity of two bean cultivars (Phaseolus vulgaris L.) submitted to cooking. Brazilian Journal of Food Technology, 21.

Silvestre MPC, Morais HA, Silva VDM, Silva MR (2013) Degree of hydrolysis and peptide profile of whey proteins using pancreatin. Nutrire Rev Soc Bras Aliment Nutr 38(3):278-290

Singh R, Kumar M, Mittal A, Mehta PK (2017) Microbial metabolites in nutrition, healthcare and agriculture. 3 Biotech 7(1):15 
Song T, Yin H, Chen J, Huang L, Jiang J, He T, Huang H, Hu X (2016) Survival advantage depends on cecal volume rather than cecal length in a mouse model of cecal ligation and puncture. J Surg Res 203(2):476-482

Umayaparvathi S, Meenakshi S, Vimalraj V, Arumugam M, Sivagami G, Balasubramanian T (2014) Antioxidant activity and anticancer effect of bioactive peptide from enzymatic hydrolysate of oyster (Saccostrea cucullata). Biomed Prev Nutr 4(3):343-353

Wang R, Shaarani SM, Godoy LC, Melikoglu M, Vergara CS, Koutinas A, Webb C (2010) Bioconversion of rapeseed meal for the production of a generic microbial feedstock. Enzym Microb Technol 47(3):77-83

Xiao CW (2008) Health effects of soy protein and isoflavones in humans. J Nutr 138(6):1244S-1249S

Yang J, Wu X-b, Chen H-1, Sun-waterhouse D, Zhong H-b, Cui C (2019) A value-added approach to improve the nutritional quality of soybean meal byproduct: enhancing its antioxidant activity through fermentation by Bacillus amyloliquefaciens SWJS22. Food Chem 272:396-403

Yang R, Zhang Z, Pei X, Han X, Wang J, Wang L, Long Z, Shen X, Li Y (2009) Immunomodulatory effects of marine oligopeptide preparation from chum salmon (Oncorhynchus keta) in mice. Food Chem 113(2):464-470

Zhang Y, Shi C, Wang C, Lu Z, Wang F, Feng J, Wang Y (2018) Effect of soybean meal fermented with Bacillus subtilis BS12 on growth performance and small intestinal immune status of piglets. Food Agric Immunol 29(1):133-146

Zhong W, Qian K, Xiong J, Ma K, Wang A, Zou Y (2016) Curcumin alleviates lipopolysaccharide induced sepsis and liver failure by suppression of oxidative stress-related inflammation via $\mathrm{PI} 3 \mathrm{~K} / \mathrm{AKT}$ and NF- $\mathrm{kB}$ related signaling. Biomed Pharmacother 83:302-313

Publisher's note Springer Nature remains neutral with regard to jurisdictional claims in published maps and institutional affiliations. 